\title{
Analysis of the relationship between fasting serum leptin levels and estimates of beta-cell function and insulin sensitivity in a population sample of $\mathbf{3 8 0}$ healthy young Caucasians
}

\author{
S M Echwald ${ }^{1}$, J O Clausen ${ }^{2}$, T Hansen ${ }^{1}$, S A Urhammer ${ }^{1}$, L Hansen ${ }^{1}$, B Dinesen ${ }^{1}$, K Borch-Johnsen ${ }^{1}$ \\ and $O$ Pedersen ${ }^{1}$ \\ ${ }^{1}$ Steno Diabetes Center and Hagedorn Research Institute, Copenhagen, Denmark and ${ }^{2}$ University of Copenhagen, Glostrup Hospital, \\ Glostrup Population Studies, Copenhagen, Denmark \\ (Correspondence should be addressed to S M Echwald, Steno Diabetes Center and Hagedorn Research Institute, Niels Steensens Vej 2, \\ DK-2820 Gentofte, Denmark)
}

\begin{abstract}
Objective: Circulating leptin levels correlate positively with the degree of obesity and prolonged hyperinsulinaemia increases serum leptin levels. Moreover, insulin secreting $\beta$-cells express functional leptin receptors indicating a functional relationship between leptin and insulin. The aim of this study was to examine the relationship between fasting serum leptin levels and measures of insulin sensitivity and $\beta$-cell function in a population-based sample of 380 young healthy Caucasians.

Design and Methods: Multiple regression analysis was employed to analyse the relationship between fasting serum leptin levels and levels of fasting serum insulin, insulin sensitivity index and acute insulin response (AIR) in a population-based study of 380 young healthy Caucasians who underwent a combined intravenous glucose and tolbutamide tolerance test.

Results and Conclusion: Serum leptin levels were positively correlated to measures of adiposity and were 3.2 times higher in women than in men $(P<0.00001)$. In multiple regression analyses adjusting for age, percentage body fat, waist circumference and maximal aerobic capacity, a significant positive correlation was observed between the fasting serum leptin concentrations and both fasting serum insulin levels $(P<0.0001)$ and AIR $(P=0.014)$ for women. No significant interrelation of these variables was found in men. However, for both genders a significant negative correlation was observed between fasting serum leptin levels and measures of insulin sensitivity index $(P=0.007)$.
\end{abstract}

European Journal of Endocrinology 140 180-185

\section{Introduction}

Leptin is a secreted protein, expressed almost exclusively in white adipose tissue. The protein has hormonal effects on food intake and energy expenditure mediated through hypothalamic leptin receptors (1). Loss-offunction mutations in the gene encoding leptin are responsible for autosomally recessive inherited obesity associated with hyperinsulinaemia and diabetes in rodents (2) and in rare cases of human obesity (3). In most humans as well as rodents the levels of both circulating leptin and leptin mRNA expression correlate with the degree of obesity (4-6) indicating that the common form of obesity is not caused by absolute leptin deficiency. However, receptors for leptin are expressed in several tissues other than adipocytes and hypothalamic cells which may indicate that the leptin protein has regulatory functions in other tissues $(7,8)$.

Recent in vitro studies have shown that circulating leptin can counteract the effects of insulin in both muscle (9) and adipocytes (10), thus inducing peripheral insulin resistance, whereas other studies indicate that leptin may stimulate glucose metabolism in muscle (11). These findings indicate that leptin may have direct effects on peripheral insulin action in vivo. Studies in humans have shown positive correlations between circulating leptin levels and fasting serum insulin levels (12-15) and negative correlations between fasting serum leptin and insulin sensitivity $(12,16)$, independently of measures of body fat contents. These findings together with studies showing that prolonged hyperinsulinaemia in humans can increase serum leptin levels indicate that leptin may influence insulin production or sensitivity in humans (17-19).

Moreover, human as well as rodent pancreatic $\beta$-cells express mRNA for the long form of the leptin receptor and show binding of recombinant leptin $(7,8)$. In vitro studies have demonstrated that leptin inhibits glucosestimulated insulin release from isolated rat islets as well as perfused rat pancreas $(7,8,20)$, whereas one study 
showed no effect of leptin on insulin or glucagon release (21). In relation to these in vitro data, one previous study has shown that in women circulating leptin levels correlate positively with measures of acute insulin response (AIR) (22) which could reflect a direct effect of leptin on $\beta$-cell function. Thus, although the human studies have comprised relatively small numbers of subjects so far, there is evidence that leptin may influence both insulin sensitivity as well as insulin secretion in man.

The aim of the present study was, therefore, to examine the relationships between fasting serum leptin levels and insulin sensitivity and fasting serum insulin levels and to explore the associations between fasting serum leptin and measures of AIR in an extensively characterised population-based sample of 380 young healthy subjects.

\section{Subjects and methods}

\section{Phenotype study of a random sample of young healthy Caucasians}

Three hundred and eighty subjects, 186 men and 194 women, were randomly recruited from a population of young healthy subjects aged 18-32 years, who in $1979 / 1980$ and again in 1984/1985 had participated as children in an epidemiological blood pressure survey in a representative specified part of Copenhagen. Physiological characteristics of this cohort have been presented previously (23). In short, anthropometric measures (height, weight, waist and hip circumference) as well as measures of insulin sensitivity, $\beta$-cell function, physical fitness and serum lipids were recorded (23). Insulin sensitivity index was estimated from an intravenous glucose tolerance test in combination with intravenous injection of tolbutamide as previously described (23). AIR was determined as the area under the insulin curve during the first $8 \mathrm{~min}$ after glucose injection, as reported (23). Body fat content was estimated by a bioimpedance technique as described previously $(23,24)$.

\section{Measurement of serum leptin}

Serum leptin levels were measured using a human leptin RIA kit (Linco, St Charles, MO, USA) (25). Serum samples $(100 \mu \mathrm{l})$ were analysed in duplicate for each subject as described in the Leptin RIA kit protocol. The interassay coefficient of variation was less than 0.07.

\section{Statistical analysis}

Statistical Package of Social Sciences, version 6.01 was used for statistical analyses. A $P$ value $<0.05$ (twotailed) was considered significant. For variables that were not normally distributed the natural logarithm transformed values were used. Normality was tested by visually inspecting normal distribution plots and histograms as well as residual plots of variables. From previous studies maximal aerobic capacity $\left(\mathrm{VO}_{2} \mathrm{max}\right)$ and use of contraceptive pills are known to influence insulin sensitivity (23) and are thus included in the multiple regression analyses. Where gender had a significant effect, a gender stratification was performed.

\section{Results}

\section{General anthropometric measures}

The clinical and biochemical characteristics of all 380 subjects are described in Table 1, stratified according to gender. Several measures of body fat composition were significantly different between genders, as previously described (23), e.g. the percentage mean body fat was 0.3 times higher in women than in men, whereas body mass index (BMI), total lean mass, total body weight and waist to hip ratio values were all higher in men.

Table 1 Clinical characteristics of a population sample of 380 young healthy Danish Caucasians (mean values \pm S.D.).

\begin{tabular}{|c|c|c|c|}
\hline & Men $(n=186)$ & Women $(n=194)$ & $P$ value* \\
\hline Age (year) & $25.5 \pm 3.4$ & $25.0 \pm 3.5$ & 0.127 \\
\hline Weight (kg) & $79.6 \pm 13.1$ & $64.3 \pm 11.2$ & $<0.001$ \\
\hline $\mathrm{BMI}\left(\mathrm{kg} / \mathrm{m}^{2}\right)$ & $24.1 \pm 3.4$ & $22.9 \pm 3.8$ & $<0.001$ \\
\hline Total body fat (kg) & $16.3 \pm 7.5$ & $17.7 \pm 7.9$ & 0.067 \\
\hline Body fat percentage (\%) & $20 \pm 6$ & $26 \pm 7$ & $<0.001$ \\
\hline Waist-hip ratio & $0.86 \pm 0.05$ & $0.77 \pm 0.06$ & $<0.001$ \\
\hline Fasting plasma glucose $(\mathrm{mmol} / \mathrm{l})$ & $5.2 \pm 0.5$ & $4.8 \pm 0.3$ & $<0.001$ \\
\hline Fasting serum insulin $(\mathrm{pmol} / \mathrm{l})$ & $35 \pm 21$ & $39 \pm 22$ & 0.100 \\
\hline Fasting serum C-peptide (pmol/l) & $456 \pm 158$ & $492 \pm 159$ & 0.028 \\
\hline Insulin sensitivity index $(\mathrm{Si})\left(10^{-5} \times(\mathrm{min} \times \mathrm{pmol} / \mathrm{l})^{-1}\right)$ & $15.2 \pm 8.8$ & $15.1 \pm 9.6$ & 0.948 \\
\hline Acute serum insulin response $A \cup C_{\text {Insulin }(0-8 \mathrm{~min})(\mathrm{min} \times \mathrm{pmol} / \mathrm{l})}$ & $2068 \pm 1372$ & $2430 \pm 1752$ & 0.006 \\
\hline Maximal aerobic capacity $\left(\mathrm{mlO}_{2} /(\mathrm{kg} \times \mathrm{min})\right)$ & $44 \pm 9$ & $38 \pm 8$ & $<0.001$ \\
\hline Fasting serum leptin $(\mathrm{ng} / \mathrm{ml})$ & $4.6 \pm 3.1$ & $15.0 \pm 10.7$ & $<0.001$ \\
\hline
\end{tabular}

* $P$ values for the difference between genders are indicated (independent sample $t$-test, equal variances not assumed). AUC, area under curve. 


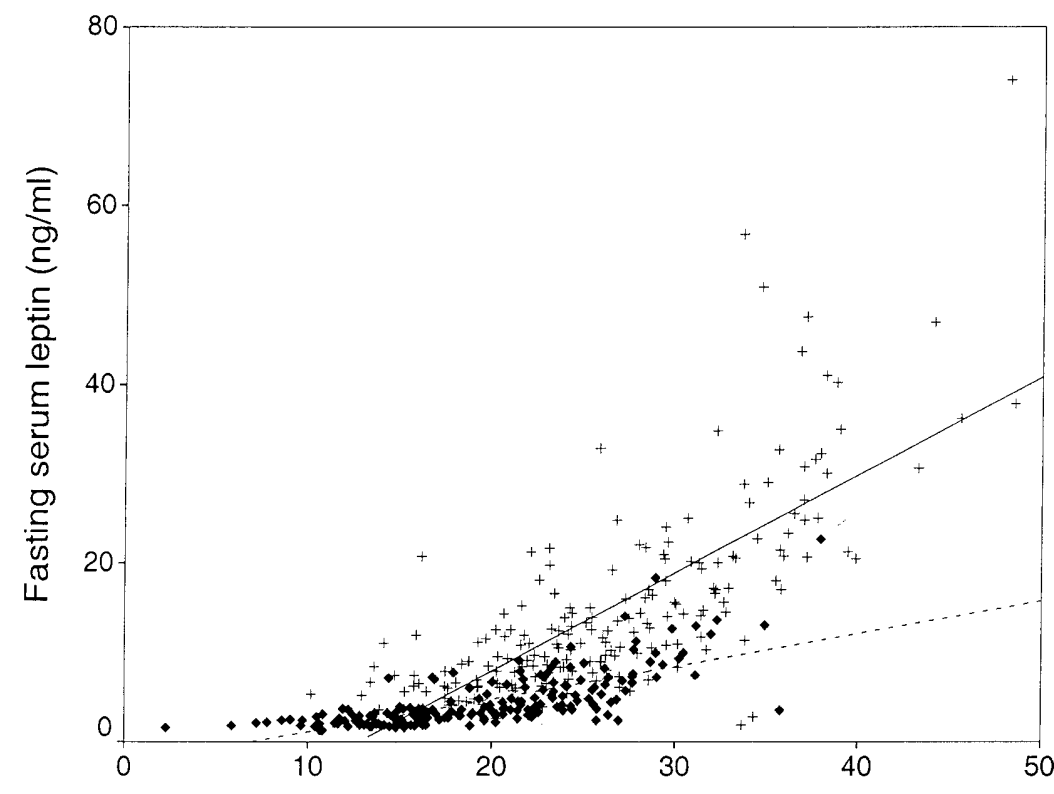

Fat percentage (\%)
Figure 1 Scatter plot of fasting serum leptin in $\mathrm{ng} / \mathrm{ml}$ vs body fat percentage measured by a bioimpedance method in 380 young healthy Caucasians. ( ) men; (+), women; dotted line, linear regression for men $\left(R^{2}\right.$ value $\left.=0.523\right)$; solid line, linear regression for women $\left(R^{2}\right.$ value $=0.551$.
Fasting serum leptin levels were on average more than three times higher in women than in men, as expected from the higher percentage fat mass in women. Fasting serum leptin levels were positively correlated with percentage body fat in both men and women (Fig. 1).

\section{Fasting serum insulin}

Levels of fasting serum insulin showed no differences between genders. A gender stratified multiple regression analysis with $\ln$ (fasting serum insulin) as dependent variable and age, percentage fat, $\mathrm{VO}_{2} \mathrm{max}$, waist circumference and circulating serum leptin as independent variables showed a strong positive correlation between circulating serum leptin levels and levels of fasting serum insulin which was independent of measures of fat mass. This correlation was, however, only found in women (Table 2).

\section{Insulin sensitivity (Si)}

Performing a multiple regression analysis with $\ln (\mathrm{Si})$ as dependent variable and age, percentage fat mass, waist circumference, $\mathrm{VO}_{2}$ max and fasting serum leptin

Table 2 Gender stratified multiple regression analysis using In(fasting insulin) as dependent variable.

\begin{tabular}{|c|c|c|c|c|}
\hline & \multirow[b]{2}{*}{ Regression coefficient } & \multicolumn{2}{|c|}{$95 \% \mathrm{Cl}$} & \multirow[b]{2}{*}{$P$ value } \\
\hline & & Lower & Upper & \\
\hline \multicolumn{5}{|l|}{ Men } \\
\hline (Constant) & 2.6 & 1.6 & 3.6 & $<0.001$ \\
\hline Age & -0.029 & -0.047 & -0.011 & 0.002 \\
\hline Fat percentage & -0.004 & -0.023 & 0.015 & 0.693 \\
\hline Waist circumference & 0.024 & 0.012 & 0.037 & $<0.001$ \\
\hline Fasting serum leptin & 0.023 & -0.008 & 0.053 & 0.150 \\
\hline Maximum aerobic capacity & -0.011 & -0.019 & -0.003 & 0.010 \\
\hline \multicolumn{5}{|l|}{ Women } \\
\hline (Constant) & 3.1 & 2.2 & 4.0 & $<0.001$ \\
\hline Age & -0.039 & -0.056 & -0.021 & $<0.001$ \\
\hline Fat percentage & -0.025 & -0.043 & -0.007 & 0.006 \\
\hline Waist circumference & 0.026 & 0.014 & 0.038 & $<0.001$ \\
\hline Fasting serum leptin & 0.020 & 0.012 & 0.029 & $<0.001$ \\
\hline Maximum aerobic capacity & -0.005 & -0.014 & 0.004 & 0.250 \\
\hline
\end{tabular}

$\mathrm{Cl}$, confidence interval; Constant, constant in regression equation. 
Table 3 Multiple regression analysis using $\ln (\mathrm{Si})$ as dependent variable.

\begin{tabular}{lcccr}
\hline & & \multicolumn{2}{c}{$95 \%$ Cl } & \\
\cline { 3 - 3 } & Regression coefficient & Lower & Upper & P value \\
\hline (Constant) & 3 & 2.8 & 5.0 & $<0.001$ \\
Age & 0.025 & 0.009 & 0.041 & 0.002 \\
Fat percentage & 0.016 & -0.001 & 0.032 & 0.061 \\
Waist circumference & -0.034 & -0.045 & -0.024 & $<0.001$ \\
Fasting serum leptin & -0.013 & -0.022 & -0.003 & 0.007 \\
Maximum aerobic capacity & 0.017 & 0.009 & 0.024 & $<0.001$ \\
Gender & -0.199 & -0.429 & 0.031 & 0.090 \\
\hline
\end{tabular}

$\mathrm{Cl}$, confidence interval; $\mathrm{Si}$, insulin sensitivity index; Constant, constant in regression equation.

as independent variables, $\ln (\mathrm{Si})$ was negatively associated with fasting serum leptin levels independently of body fat in both genders (Table 3).

\section{Acute insulin response (AIR)}

Performing a gender stratified multiple regression analysis with $\ln (\mathrm{AIR})$ as dependent variable and age, percentage fat mass, waist circumference, $\mathrm{VO}_{2} \max$ and leptin as independent variables, there was a significant positive correlation with fasting serum leptin levels among women (Table 4). The inclusion of fasting serum insulin levels as a dependent variable in the multiple regression analysis eliminated the correlations between fasting serum leptin and AIR (data not shown).

\section{Discussion}

In the present study multiple regression analysis showed a significant positive correlation between circulating fasting leptin levels and fasting serum insulin levels for women even when percentage body fat was included in the analysis (Table 2). This finding is in accordance with previous studies confirming a positive correlation between circulating levels of leptin and insulin (12-15). This relationship may reflect either a direct effect of leptin on pancreatic $\beta$-cells increasing insulin secretion or a correlation between leptin and insulin sensitivity, where decreased insulin sensitivity may induce an adaptive increase in fasting insulin levels.

Recent in vitro studies show that circulating leptin levels influence energy metabolism in both muscle and adipocyte cells $(9-11)$. Using multiple regression analysis we have demonstrated a significant negative correlation between fasting serum leptin and Si for both genders, indicating a potential impact of leptin on whole body insulin sensitivity. A negative correlation between measures of $\mathrm{Si}$ and fasting serum leptin levels has previously been reported $(12,16)$. However, fasting serum insulin levels correlate well with $\mathrm{Si}(23)$ and thus fasting leptin levels could be correlated to Si through fasting insulin levels. As the in vitro data are contradictory on this issue, the nature of the correlation between fasting serum leptin and $\mathrm{Si}$ is difficult to

Table 4 Gender stratified multiple regression analysis using $\ln (\mathrm{AIR})$ as dependent variable in 186 male and 194 female young Danish Caucasians.

\begin{tabular}{lcccr}
\hline & & \multicolumn{2}{c}{$95 \% \mathbf{C l}$} \\
\cline { 3 - 3 } & Regression coefficient & Lower & Upper & P value \\
\hline Men & & & & \\
(Constant) & 7.1 & 5.4 & 8.7 & $<0.001$ \\
Age & -0.037 & -0.072 & -0.003 & 0.034 \\
Fat percentage & 0.009 & -0.027 & 0.044 & 0.627 \\
Waist circumference & 0.012 & -0.012 & 0.036 & 0.338 \\
Fasting serum leptin & 0.023 & -0.033 & 0.080 & 0.414 \\
Women & & & & \\
(Constant) & 6.5 & 5.5 & 7.5 & $<0.001$ \\
Age & -0.011 & -0.036 & 0.014 & 0.370 \\
Fat percentage & -0.023 & -0.048 & 0.002 & 0.077 \\
Waist circumference & 0.024 & 0.007 & 0.041 & 0.007 \\
Fasting serum leptin & 0.015 & 0.003 & 0.027 & 0.014 \\
\hline
\end{tabular}

$\mathrm{Cl}$, confidence interval; AIR, acute insulin response; Constant, constant in regression equation. 
evaluate. The finding from several studies that prolonged hyperinsulinaemia $(>4 \mathrm{~h})$ can increase circulating leptin levels in humans (17-19) and also that insulin has been shown to be a potent stimulator of leptin secretion in vitro (26) underscore the possibility that a regulatory mechanism may exist between serum leptin and serum insulin levels and further points to insulin as the primary determining factor. However, as the ob mice lacking leptin are both obese and insulin resistant (2), leptin does not seem to constitute an essential part of the insulin resistance conveyed by obesity.

On the other hand, the presence of leptin receptors on $\beta$-cells $(7,27)$ and their sensitivity to leptin in in vitro studies $(7,8,20)$ may also indicate that leptin affects $\beta$-cell function directly. We therefore analysed the relation between circulating leptin levels and measures of AIRs using multiple regression analysis. Including, among many other factors, fat mass as a dependent factor in the analysis, AIR in women showed a positive correlation to fasting serum leptin levels. As the positive correlation between fasting serum insulin levels and leptin seems to be stronger in women compared with men (28) and as a positive correlation has previously been found between circulating leptin levels and AIR to arginine and glucose in a study of 36 postmenopausal women (22), it is possible that these findings reflect a direct effect of leptin on AIRs, which appears only to be detectable in women. However, since a very strong positive correlation exists between fasting serum insulin and AIR, the correlation between fasting serum leptin and AIR may be secondary to the latter relationship (23). When including fasting serum insulin levels as an independent variable in the multiple regression analysis, the correlation between leptin and AIR disappears. Still, acute hyperglycaemia or hyperinsulimaemia do not increase circulating leptin levels in man $(29,30)$, and one could hypothesise that although long-term hyperinsulinaemia increases circulating leptin levels, a short-term effect of leptin on pancreatic $\beta$-cells and AIR might exist. Determining a primary effect of leptin on insulin secretion will, however, require further investigation. In Pima Indians, a genetic linkage has been reported between measures of AIR to an intravenous glucose challenge and a locus which encompasses the leptin receptor indicating a potential role of leptin action in controlling AIR in this ethnic group (31).

Fasting serum insulin and AIR show positive correlations to leptin levels only in women in this and other studies $(22,28)$. A possible reason for this finding could be that a higher variance is seen for leptin levels among women. However, leptin levels are also higher in women, and thus the relative variation is similar among men and women. Rather, the correlations seen in women could be due just to the higher serum leptin levels, since a potential effect of leptin would be stronger.

In summary, the fasting serum leptin level is positively correlated to both fasting serum insulin levels and AIR in women in this population sample of young healthy subjects. Moreover, Si is negatively correlated to fasting serum leptin levels in both genders. As described by Clausen et al. (23), AIR, fasting serum insulin and $\mathrm{Si}$ are highly correlated to measures of body fat as is circulating leptin levels, making body fat content a possible confounder in the interpretation of the results obtained in the correlation analysis. However, the multiple regression analysis indicates that fasting serum leptin may be independently correlated to measures of fasting serum insulin, insulin responses and insulin sensitivity. Whether these results point to a direct effect of leptin on $\beta$-cell function and insulin sensitivity or whether circulating insulin levels influence circulating leptin levels remain to be determined.

\section{Acknowledgements}

The study was supported by grants from the University of Copenhagen, the Danish Research Academy, the Velux Foundation, the Danish Diabetes Association, EEC Grant (BMH4-CT95-0662), Danish Medical Research Council, the Danish Heart Foundation, the Danish Hospital Foundation for Medical Research, Region of Copenhagen. The authors thank Helle Fjordvang, Lene Aabo, Bente Mottlau, Annemette Forman, Susanne Kjellberg and Hanne Damm for dedicated and careful technical assistance and Grete Lademan for secretarial support.

\section{References}

1 Bray GA. Leptin and leptinomania. Lancet 1996348 140-141.

2 Zhang YY, Proenca R, Maffei M, Barone M, Leopold L \& Friedman JM. Positional cloning of the mouse obese gene and its human homologue. Nature 1994372 425-432.

3 Montague CT, Farooqi IS, Whitehead JP, Soos MA, Rau H, Wareham NJ et al. Congenital leptin deficiency is associated with severe early-onset obesity in humans. Nature 1997387 903-908.

4 Maffei M, Halaas J, Ravussin E, Pratley RE, Lee GH, Zhang Yet al. Leptin levels in human and rodent - measurement of plasma leptin and OB RNA in obese and weight-reduced subjects. Nature Medicine 19951 1155-1161.

5 Considine RV, Sinha MK, Heiman ML, Kriauciunas A, Stephens TW, Nyce MR et al. Serum immunoreactive leptin concentrations in normal weight and obese humans. New England Journal of Medicine 1996334 292-295.

6 Lonnqvist F, Arner P, Nordfors L \& Schalling M. Overexpression of the obese $(o b)$ gene in adipose tissue of human obese subjects. Nature Medicine 19951 950-953.

7 Emilsson V, Liu YL, Cawthorne MA, Morton NM \& Davenport M. Expression of the functional leptin receptor messenger RNA in pancreatic islets and direct inhibitory action of leptin on insulin secretion. Diabetes 199746 313-316.

8 Kieffer TJ, Keller RS, Leech CA, Holz GG \& Habener JF. Leptin suppression of insulin secretion by the activation of ATP-sensitive $\mathrm{K}^{+}$channels in pancreatic beta-cells. Diabetes 199746 1087-1093.

9 Muoio DM, Dohn GL, Fiedorek FT, Tapscott EB \& Coleman RA. Leptin directly alters lipid partitioning in skeletal muscle. Diabetes 199746 1360-1363. 
10 Muller G, Ertl J, Gerl M \& Preibisch G. Leptin impairs metabolic actions of insulin in isolated rat adipocytes. Journal of Biological Chemistry 1997272 10585-10593.

11 Berti L, Kellerer M, Capp E \& Haring HU. Leptin stimulates glucose transport and glycogen synthesis in $\mathrm{C} 2 \mathrm{C} 12$ myotubes - evidence for a PI3-kinase mediated effect. Diabetologia 199740 606-609.

12 Haffner SM, Miettinen H, Mykkanen L, Karhapaa P, Rainwater DL \& Laakso M. Leptin concentrations and insulin sensitivity in normoglycemic men. International Journal of Obesity 199721 393-399.

13 Havel PJ, Kasimkarakas S, Mueller W, Johnson PR, Gingerich RL \& Stern JS. Relationship of plasma leptin to plasma insulin and adiposity in normal weight and overweight women - effects of dietary fat content and sustained weight-loss. Journal of Clinical Endocrinology and Metabolism 199681 4406-4413.

14 Dagogojack S, Fanelli C, Paramore D, Brothers J \& Landt M. Plasma leptin and insulin relationships in obese and non-obese humans. Diabetes 199645 695-698.

15 Schwartz MW, Prigeon RL, Kahn SE, Nicolson M, Moore J, Morawiecki A et al. Evidence that plasma leptin and insulin levels are associated with body adiposity via different mechanisms. Diabetes Care $1997201476-1481$.

16 Segal KR, Landt M \& Klein S. Relationship between insulin sensitivity and plasma leptin concentration in lean and obese men. Diabetes 199645 988-991.

17 Utriainen T, Malmstrom R, Makimattila S \& YkiJärvinen H. Supraphysiological hyperinsulinemia increases plasma leptin concentrations after $4 \mathrm{~h}$ in normal subjects. Diabetes 199645 1364-1366.

18 Kolaczynski JW, Nyce MR, Considine RV, Boden G, Nolan JJ, Henry $\mathrm{R}$ et al. Acute and chronic effect of insulin on leptin production in humans - studies in vivo and in vitro. Diabetes 1996 45 699-701.

19 Malmstrom R, Taskinen MR, Karonen SL \& Ykijärvinen H. Insulin increases plasma leptin concentrations in normal subjects and patients with NIDDM. Diabetologia 199639 993-996.

20 Ishida K, Murakami T, Mizuno A, Iida M, Kuwajima M \& Shima K. Leptin suppresses basal insulin secretion from rat pancreatic islets. Regulatory Peptides 199770 179-182.

21 Leclercqmeyer V \& Malaisse WJ. Failure of leptin to counteract the effects of glucose on insulin and glucagon release by the perfused rat pancreas. Medical Science Research 199725 $257-259$.
22 Larsson H, Elmstahl S \& Ahren B. Plasma leptin levels correlate to islet function independently of body fat in postmenopausal women. Diabetes 199645 1580-1584.

23 Clausen JO, Borch-Johnsen K, Ibsen H, Bergman RN, Hougaard P, Winther $\mathrm{K}$ et al. Insulin sensitivity index, acute insulin response, and glucose effectiveness in a population-based sample of 380 young healthy Caucasians. Analysis of the impact of gender, body fat, physical fitness, and life-style factors. Journal of Clinical Investigation 199698 1195-1209.

24 Heitmann BL. Prediction of body water and fat in adult Danes from measurement of electrical impedance. A validation study. International Journal of Obesity 199014 789-802.

25 Ma ZM, Gingerich RL, Santiago JV, Klein S, Smith CH \& Landt M. Radioimmunoassay of leptin in human plasma. Clinical Chemistry $199642942-946$.

26 Wabitsch M, Jensen PB, Blum WF, Christoffersen CT, Englaro P, Heinze E et al. Insulin and cortisol promote leptin production in cultured human fat cells. Diabetes 199645 1435-1438.

27 Kieffer TJ, Heller RS \& Habener JF. Leptin receptors expressed on pancreatic beta-cells. Biochemical and Biophysical Research Communications 1996224 522-527.

28 Couillard C, Mauriege P, Prudhomme D, Nadeau A, Tremblay A, Bouchard $\mathrm{C}$ et al. Plasma leptin concentrations - gender differences and associations with metabolic risk factors for cardiovascular disease. Diabetologia 199740 1178-1184.

29 Ryan AS \& Elahi D. The effects of acute hyperglycemia and hyperinsulinemia on plasma leptin levels - its relationships with body fat, visceral adiposity, and age in women. Journal of Clinical Endocrinology and Metabolism 199681 4433-4438.

30 Vidal H, Auboeuf D, Devos P, Staels B, Riou JP, Auwerx J et al. The expression of ob gene is not acutely regulated by insulin and fasting in human abdominal subcutaneous adipose tissue. Journal of Clinical Investigation 199698 251-255.

31 Thompson DB, Sutherland J, Apel W \& Ossowski V. A physical map at 1p31 encompassing the acute insulin-response locus and the leptin receptor. Genomics 199739 227-230.

Received 30 October 1998

Accepted 2 November 1998 